\title{
New Japan Quality Management Model: Implementation Of New JIT For Strategic Management Technology
}

Manabu Yamaji, (Email: yamaji@ise.aoyama.ac.jp), Aoyama Gakuin University, Japan

Kakuro Amasaka, Aoyama Gakuin University, Japan

\begin{abstract}
In the midst of the rapid advancement of "globalization - worldwide quality competition," Japanese manufacturers are struggling for the realization of "simultaneous achievement of QCD (Quality, Cost and Delivery). Against this background, for the purpose of sharing intellectual information and strengthening cross-department cooperation, this study proposes "New Japan Quality Management Model" mainly in connection with the Quality Assurance Div. and TQM Promotion Div. Further, the effectiveness of this model is verified at Toyota. As a result, QCD was achieved simultaneously by collaboration of QA Division and TQM Division.
\end{abstract}

Keywords: New Japan Quality Management Model, New JIT, QCD

\section{INTRODUCTION}

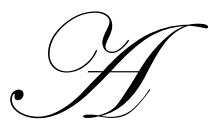

t present, leading companies are promoting global production strategies to realize "same quality standards and simultaneous production startup worldwide". Advanced companies especially are eagerly looking for a new quality management method to supply new attractive product models ahead of their competitors to ensure their survival in the worldwide market.

A future successful global marketer must develop an excellent quality management system that impresses users and continuously provides excellent, quality products in a timely manner through corporate management. To realize manufacturing that places top priority on customers with a good QCD (Quality, Cost and Delivery) and in a rapidly changing technical environment, it is essential to create a new core principle capable of changing the work process quality of all divisions for reforming the super-short-term development production.

Against this background, for the purpose of sharing intellectual information and strengthening crossdepartment cooperation, this study proposes "New Japan Quality Management Model" mainly in connection with the Quality Assurance Div. and TQM Promotion Div. Further, the effectiveness of this model is verified at Toyota.

\section{TODAY'S MANAGEMENT TECHNOLOGY PROBLEM}

At present, "Japanese manufacturing" is facing the need for 2 major reforms. One is the realization of the shortest possible lead time for development, production, and sales to respond to the shortening life cycle of products, which is due to the sophistication and diversification of customers' needs. The other is the globalization of production bases to enhance the product power.

Under such a circumstance, as shown in Figure1, the managers of leading Japanese corporations are keenly interested in the establishment of "proposal-based development of new merchandise and new products" as well as "next generation production method," and they give priority to the development of "new marketing methods."

This trend is indicative of the fact that the creation of new management technology for contributing to sharing intellectual information and strengthening cross-department cooperation is currently a pressing issue and the 
basis for realizing the above development. (Amasaka 2004; 2005) Above all, manufacturers endeavoring to become global companies are required to collaborate with not only affiliated companies, but also with non-affiliated companies to achieve harmonious coexistence among them based on cooperation and competition.

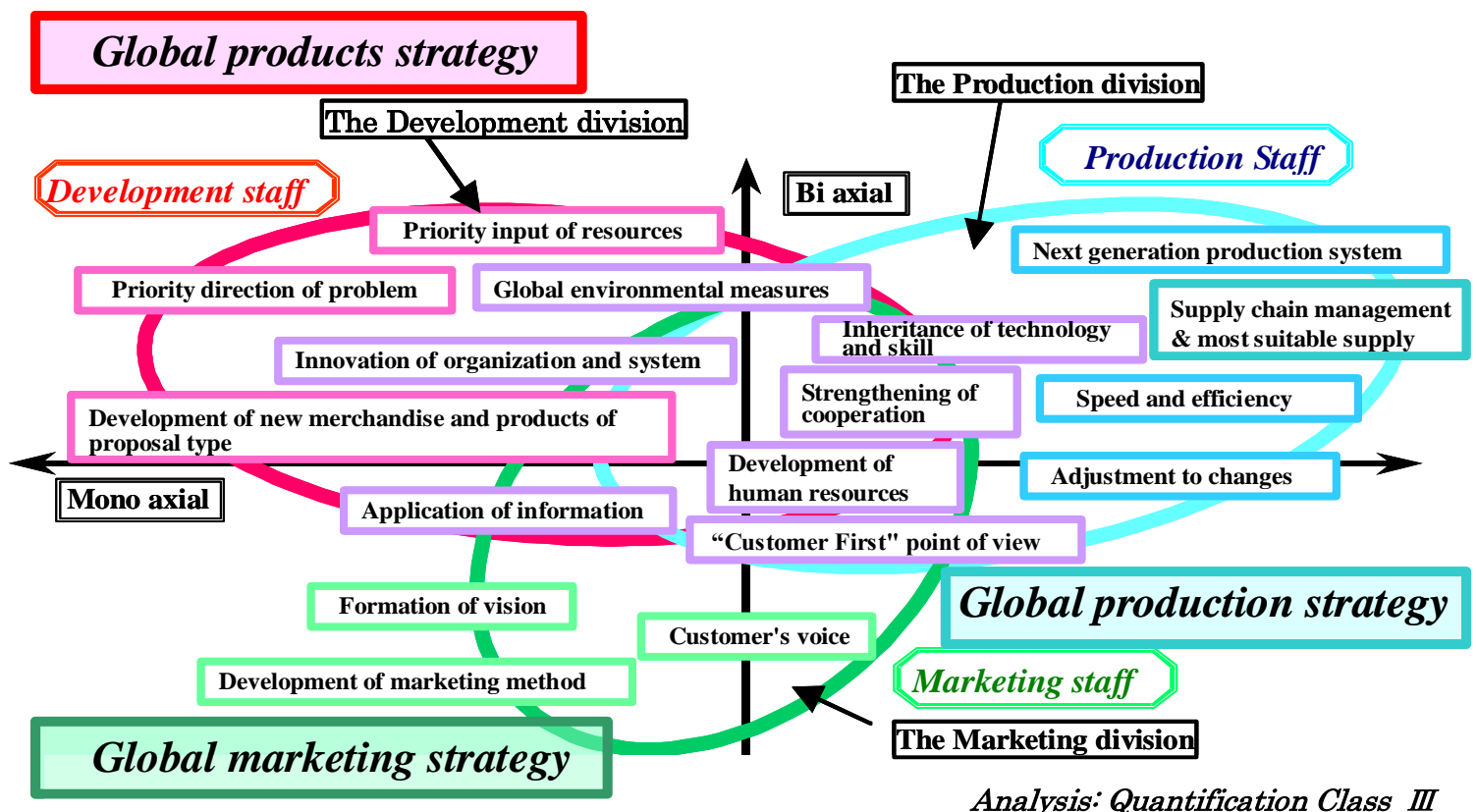

Figure 1: Management technology issues throughout the Advanced Companies

\section{FROM JIT TO NEW JIT STRATEGY}

\section{Traditional Japanese Production System And Quality Management: JIT}

One of the greatest contributions that Japan made to the world is "JIT". JIT is a production system that enables provision of what customers desire when they desire it. JIT is also introduced in a number of enterprises in the United States and Europe as a key management technology. (Roos, et al. 1990; Taylor 2001; Womack 1994)

The Japanese-style production system represented by the current Toyota Production System, called JIT, is a production system which has been developed by Toyota. (Ohno 1977) Implementing TQM in its production process, this production system aims to achieve the simultaneous of quality and productivity in pursuit of maximum rationalization while recognizing the principle of cost reduction. (Amasaka 2002)

This is the essential concept of JIT and therefore, these have been positioned as a core part of Toyota's management technology and often likened to the wheels on both sides of a vehicle. However, Toyota's production system, which is representing the Japanese- style production system today, has already been developed as an internationally shared system, known as a Lean System and is no longer an exclusive technology of Toyota in Japan.

In the Western countries also, the importance of quality control has been recognized through the studies on the Japanese TQM. As a result, TQM activities have been increasingly popular. Therefore, the superiority in quality of Japanese products assured by the Japanese-style quality control has been gradually undermined in recent years. (Amasaka 2002; 2003; 2007; Amasaka eds. 2007) 


\section{Significance Of The New JIT Establishment}

In the midst of the rapid advancement of "globalization - worldwide quality competition," Japanese manufacturers are struggling for the realization of "simultaneous achievement of QCD" of "reduction in development period," "assurance of high quality," and "production at low cost." It can be said that they are truly facing an era of new "manufacturing" in the process of "simultaneous achievement of QCD."

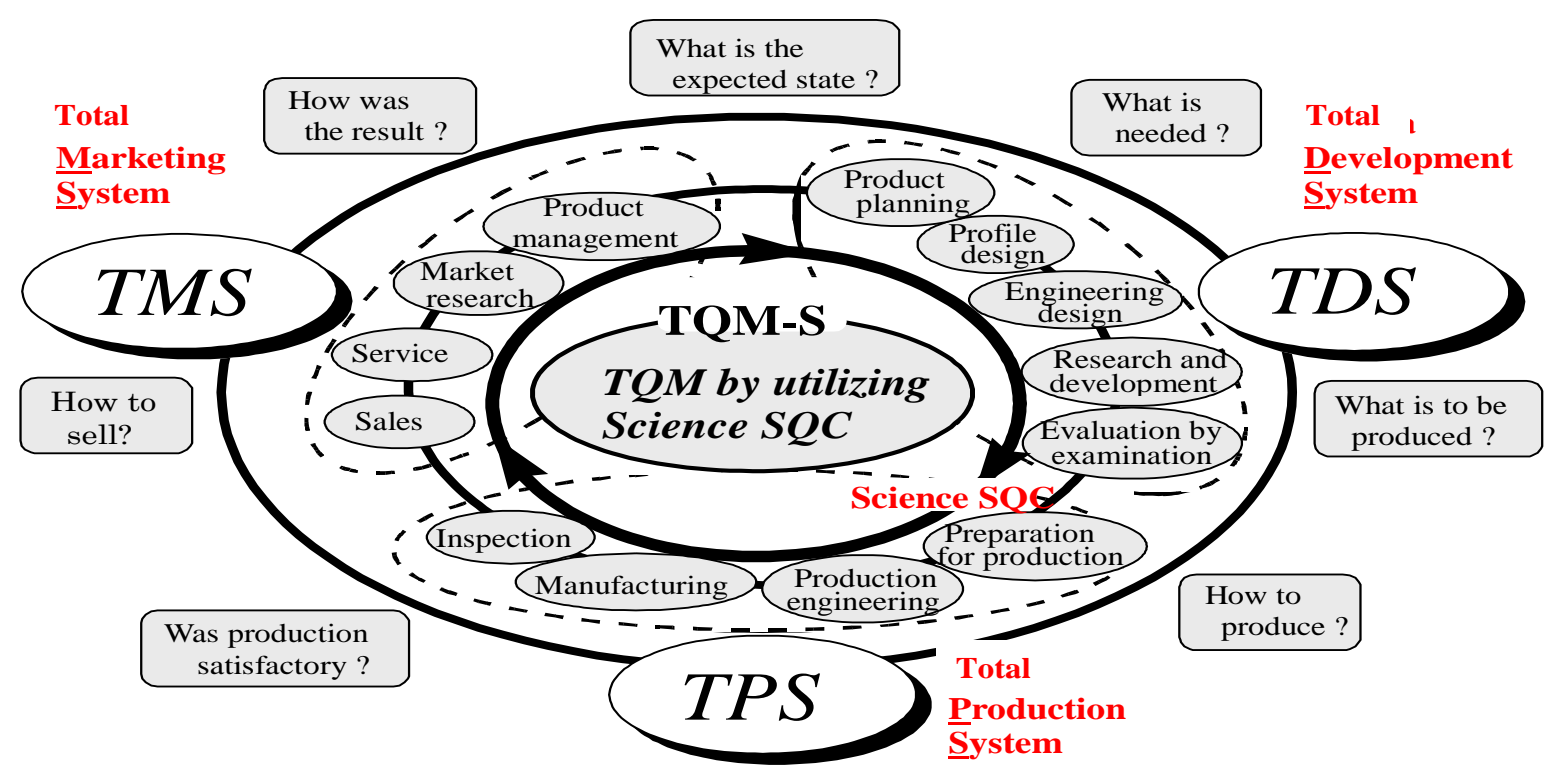

Figure 2: New JIT, A New Management Technology Principle Principle

In order for advanced manufactures to manufacture attractive products, it is deemed necessary to create now "the principle of a new, next generation management technology." This will enable a high linkage of business process cycles as a principle of behavior for systematic and organizational transformation of the whole process consisting not only of each division of sales promotion, development/design, and production, but also business management, office operations, and suppliers into an organic body. (Amasaka 2005)

\section{New JIT, A New Management Technology Principle}

From such a standpoint, the authors (Amasaka 2002) are proposing "a new principle of next generation management technology - New JIT" as shown in Figure 2 The hardware system of "New JIT" is composed of TMS, $T D S$, and TPS and these are the core technologies indispensable for establishing a new management technology. Furthermore, with regard to the deployment of "strategic quality management" vital for prevailing in the recent "worldwide quality competition," the authors (Amasaka 2005) are proposing a new principle of quality management called "Science TQM (Amasaka eds. 2007)."

This incorporates "Science SQC" as a software system for improving the quality of the business process of all departments. By these means, the authors (Amasaka 2004; 2005) have been verifying the effectiveness of "New JIT" as "a new management technology strategy model" which can dramatically advance the conventional JIT through its application to leading corporations in Japan. (Amasaka et al. 2004) 
At present, New JIT for the evolution of management technology into management strategy proved effective in a number of cases in Toyota and other companies, and will be introduced to many other countries (Amasaka 2001a; 2001b; 2005; Amasaka and Osaki 2002; Amasaka, et al. 2004; Amasaka and Yamaji 2006)

\section{CURRENT SITUATION OF QUALITY MANAGEMENT IN THE JAPANESE MANUFACTURING}

Taking a careful look at the repeated cases of market recall happening in the manufacturing sector recently, it can be deduced that it is not only an "issue of quality of products," but also a severe challenge presented to the "reliability of products - the way of quality management" of Japanese manufacturing. The authors surmise that such a situation is pointing to the brittle fatigue of "the function of quality assurance - reliability of products," which once was a strong point of Japanese manufacturing.

Also it suggests a possible idling of "the function of quality management - reliability of human resources." (Amasaka 2004) Under such a circumstance, there are many studies abroad for globalization (Lagrosen 2004; Ljungström 2005) and TQM (Hoogervorst 2005; Burke 2005; Kakkar and Narag 2007; Prajogo 2007). Basically, the Quality Assurance Div. and TQM Promotion Div. work in harmony as a cornerstone of "quality management" which "manages the quality" of each of the related divisions so as to keep circulating normally the business cycles for quality management.

However, since the burst of the bubble economy, as if epitomizing the advantage of a Japanese production system, (i) "super mass production - automation of production and automation of inspection" has been promoted. (ii) As "quality defects" were reduced in the production process, it was thought that, relatively speaking, (iii) "quality assurance and inspection do not produce added value," (iv) and therefore, the organization/operation of Quality Assurance Div. or Inspection Div. was scaled down or mere routine work was introduced therein, and (v) activities for creating new functions for quality assurance or TQM have been stagnating. For the past 10 plus years, efforts for promoting customer-first "manufacturing - high quality assurance" which enhances the customer value as well as "human resource development - high reliability of total business process" have been neglected and therefore are lagging behind. (Amasaka et al. 2004; Goto 1999) Though overseas local production has been advancing recently along with a rapid expansion of global production, an uphill battle has been fought for the "building up of quality" which can match Japanese manufacturing.

Quality Assurance related divisions are busy with cleaning up the mess of "quality defect" cases, and TQM Promotion Div. has been slack in functioning as a cultivator of human resources with fighting potential, giving too much "emphasis on TQM education for TQM promotion." (Evans and Lindsay 1995)

\section{Basic Principle Of Quality Management}

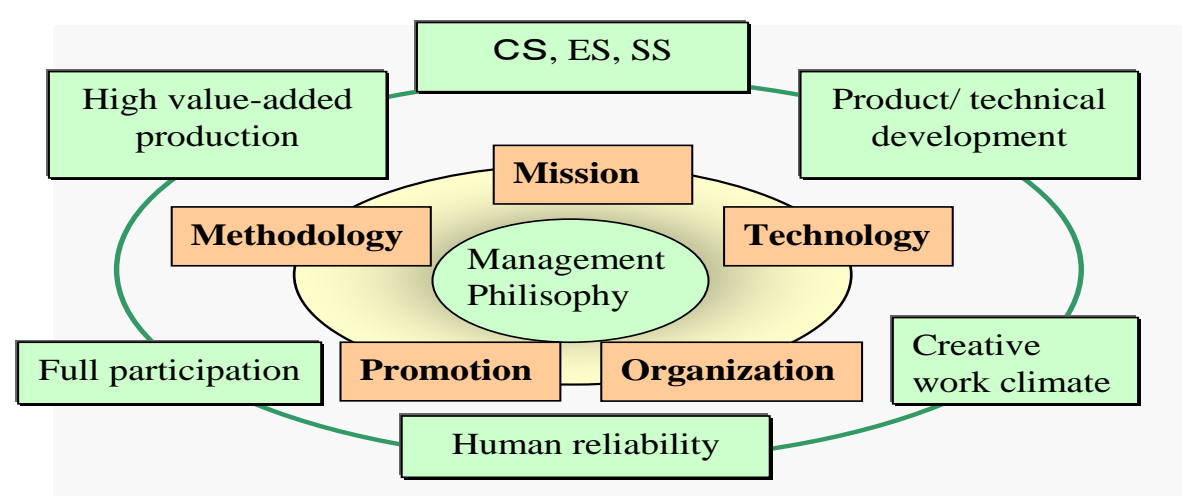

Figure3: Basic Principle of Quality Management

Having said the above, it is deemed necessary now to go back to the "basic principle of quality management" as shown in Figure3, and to reform the quality assurance function as well as the TQM promotion function which advances the former. (Evans and Lindsay 1995; Yamaji and Amasaka 2006) 
This basic principle involves, as a management philosophy, establishment of Mission, Methodology, Promotion, Organization, and Technology, and realization of CS (Customer Satisfaction), ES (Employee Satisfaction), SS (Social Satisfaction), high added value products, product development/ technology development, creative corporate environment, human reliability, and full participation. It is vital to strategically deploy this basic principle.

\section{New Japan Quality Management Model}

Considering the importance of scientific quality management, and on the basis of the "New JIT" which has verified the effectiveness of the "stratified task team" in TQM promotion, as well as the universality of the "basic principle of quality management" presented in the previous chapter, the authors (Yamaji, et al., 2006) here propose, as indicated in Figure 4, a next generation type, advanced model of quality management, "New Japan Quality Management Model" The following are the functions of the Quality Assurance and TQM Promotion related divisions: as corporate environment factors for succeeding in "global production," customer-first, (1) CS, ES, SS, (2) for high quality assurance and as a strategic factor to realize it, (3) in order to simultaneously achieve QCD, and (4) success in global partnering. Intellectual productivity, company/affiliate/ non-affiliate linkage is realized by these. So (5) evolution of quality management is achieved.

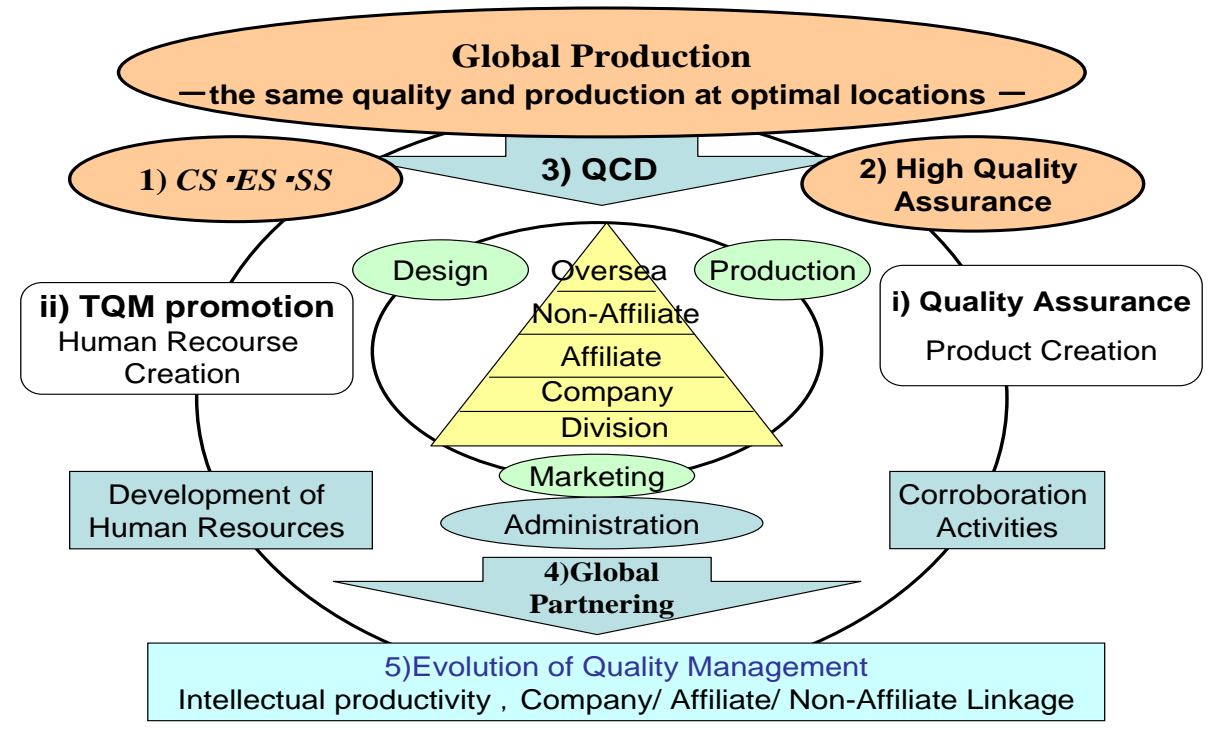

Figure 4: "New Japan Quality Management Model"

More specifically, the (i) Quality Assurance Div. needs to promote manufacturing of high reliability, and cooperative activity across the organization is indispensable to achieve it. In the (ii) TQM Promotion Div., it is important to cultivate human resources having even higher skills, knowledge, and creativity. It is a must to continue to upgrade working the value (Yamaji et. al. 2006) or by promoting the cultivation of intelligent human resources in an effort to improve the productivity of white collar workers. In order to realize the above, global partnering which enables a strategic cooperation among divisions, such as designing, production, marketing and administration as well as the entire company, affiliated companies, non-affiliated companies, and overseas corporations, must be achieved. Improvement of intellectual productivity is simultaneous achievement of QCD utilizing this model.

\section{VERIFIED CASES OF NEW JAPAN QUALITY MANAGEMENT MODEL}

In this chapter, the degree of application of the "New Japan Quality Management Model" at Toyota Motor Corporation, and its effectiveness are discussed. 
Improvement In Painting Quality Of Chassis Parts Of Automobiles: Cooperative Activities With Affiliated And Non-Affiliated Companies

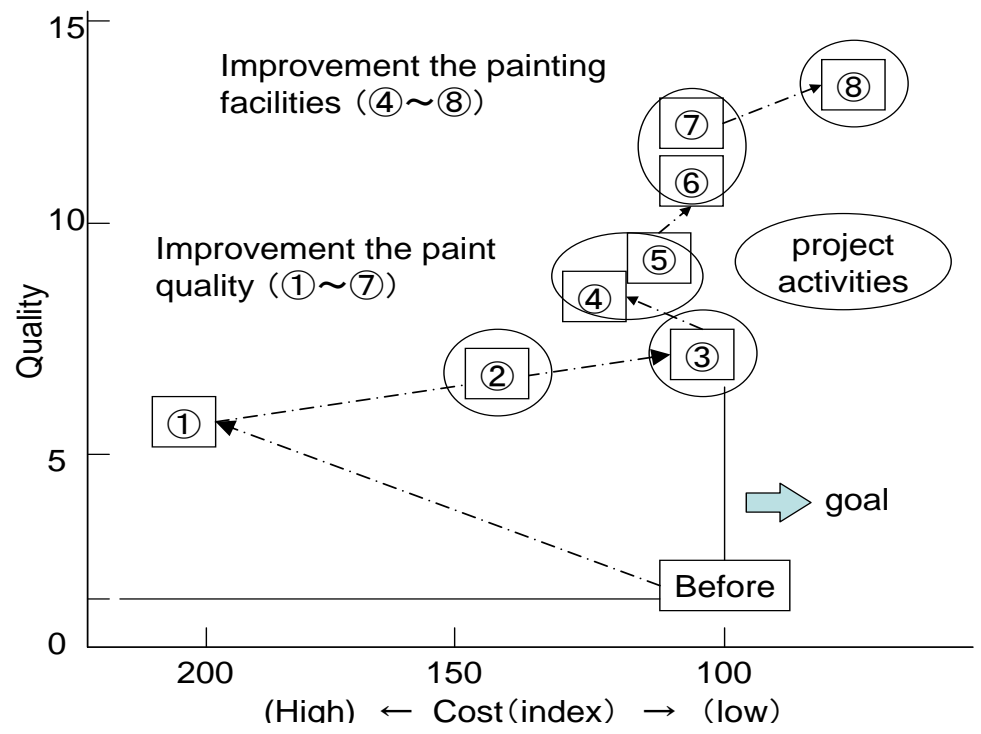

Figure 5: Improvement process of the paint

This case is simultaneous achievement of QCD for upgrading of automobile quality. Anti-corrosion has been an important issue for chassis parts of automobiles, and it has been a formidable challenge to resolve as it requires a comprehensive solution which encompasses materials, pre-treatment, paint, painting, and logistics. Conventionally, paint manufacturers and automobile manufacturers prepare paints on their own, and generally, the selection of paints was made after evaluation.

This method, however, cannot keep abreast with the sophisticated, accelerating market needs. In order to simultaneously achieve quality, cost and delivery (QCD) across different industries and segmented organizations, it is necessary for paint manufacturers and automobile manufacturers to promote project activity in cooperation all the way from paint designing to building up paint quality.

As an example of this, Toyota carried out a project through formation of a task team with its affiliated company, Aisin Chemical Co., Ltd. as well as non-affiliated company Tokyo Paint Co., Ltd. Quality Assurance Div. collected quality data in the market. TQM Promotion Div. analyzes that data.

The figure5 shows the development process of paints used for the rear axel assay of automobiles in each improvement process for cost and quality. Up until now, styrene-altered alkyd resin paint has been used. To prevent the generation of initial rust, which resulted from applying an anti-freezing agent mainly used in overseas markets, phenol-altered alkyd resin paint was adopted (Improvement 1), but as shown in the figure5, the painting cost increased. The painting cost means not only the price of paints but includes the total cost involved, such as painting operation cost, energy consumption, facility maintenance and cleaning cost, inspection cost, etc. per vehicle.

Against this background, an extensive project was launched in which the ever-increasing quality level required by the market is predicted and the target value is set in several steps for implementation in a planned manner. The first few years were spent improving the paint quality (Improvements 1 to 7 ) and after that, efforts were made in parallel to improve the painting facilities (Improvements 4 to 8 ). 
As a result, a type of paint with anticorrosive properties 10 times the conventional type was developed and the painting cost was reduced by more than $30 \%$, a considerable improvement (Amasaka 2004).

\section{Stability In Quality And Improvement In The Operating Rate Of The Welding Process}

This case is simultaneous achievement of QCD for boosting the equipment availability. For gas shield arc welding, automation using welding robots has been popularized. (Amasaka 2004) In this area, the improvement in its operating rate is an important issue. The nozzle cleaning of torches and replacement of contact tips is the cause of the declining operating rate. However, since these maintenance operations have been considered to be necessary, no major improvements have been made in this area.

Against this background, Toyota formed a task force with non-affiliated companies, Noritake Co., Limited and Toshiba Tungaloy to improve the situation. Quality Assurance Div. collected quality data in the process. TQM Promotion Div. analyzes that data. The improvement of the tip surface brought about through the cooperative activity of this task force is illustrated in the figure6. The technology involved here is such that it would improve the anti-wear properties by preventing sputter from depositing without lowering the power feeding efficiency needed for welding. This contributes to extending the life of the tips and to regularizing their replacement. (A) $\mathrm{Cr}-\mathrm{Cu}$ alloy has been used up until now. (C) to (G) are applications in which the alloy of (A) is coated with toughened ceramic layers.

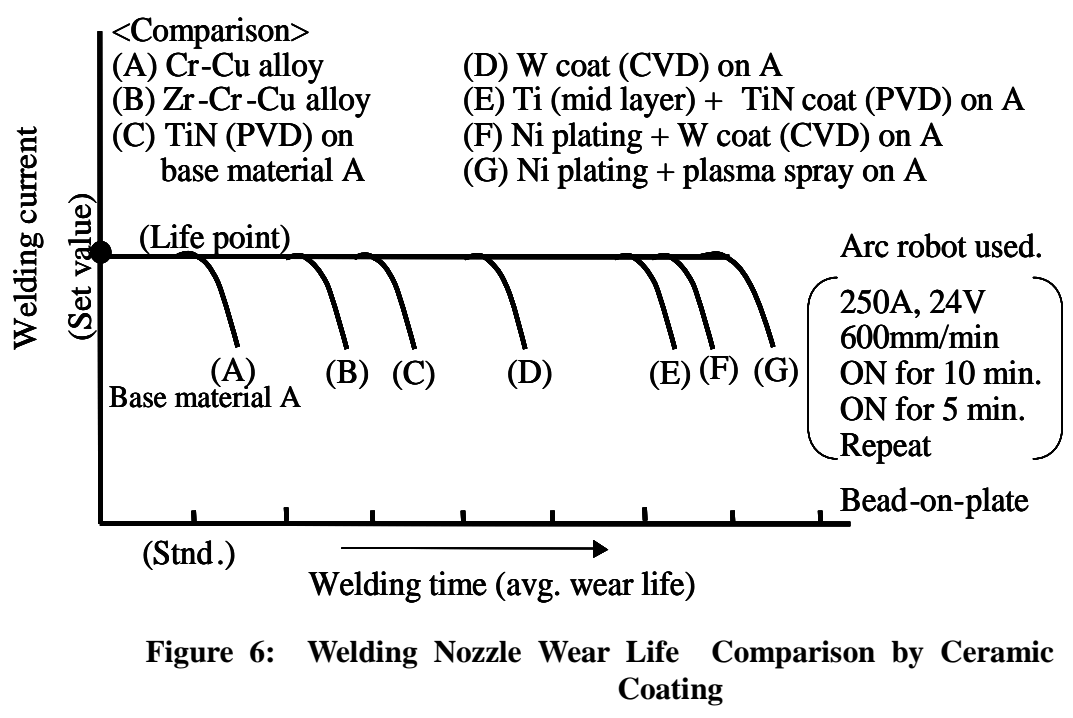

Through these activities, both manufactures applied for 19 patents. Moreover, the nozzle cleaning is not necessary any more, and the life of the tips has been extended dramatically. As a result, the operating rate has increased by $8 \%$ (from $80 \%$ to $88 \%$ ).

\section{CONCLUSION}

Considering the importance of scientific quality management, and on the basis of the "New JIT", as well as the universality of the "basic principle of quality management", this study proposed "New Japan Quality Management Model" mainly in connection with the Quality Assurance Div. and TQM Promotion Div. This model is aimed for sharing intellectual information and strengthening cross-department cooperation. Further, the effectiveness of this model is verified at Toyota. As a result, QCD for upgrading of automobile quality and boosting the equipment availability was achieved simultaneously by collaboration of QA Division and TQM Division. 


\section{REFERENCES}

1. Amasaka K., A Study of Flyer Advertising Affect When TMS-S at Toyota, Proc. of the $12^{\text {th }}$ Annual Conference of Production and Operations Management Society, Orland, Florida, 2001, 1-8 (CD-ROM).

2. Amasaka, K., Proposal of Marketing SQC to Revolutionize Dealers' Sales Activities, Proc. of the 16th International Conference on Production Research, Prague, Czech Public, 2001, 1-9 (CD-ROM).

3. Amasaka, K., New JIT, A New Management Technology Principle at Toyota, International Journal of Production Economics, 80, 2002, 135-144

4. Amasaka, K., Development of Science TQM, A New Principle of Quality Management: Effectiveness of Strategic Stratified Task Team at Toyota, International Journal of Production Research, 42(17), 2003, 3691-3706.

5. Amasaka K., Applying New JIT-A Management Technology Strategy Model at Toyota - Strategic QCD Studies with Affiliated and Non-affiliated Suppliers, Proc. of the $2^{\text {nd }}$ World Conference on Production and Operations Management Society, Cancun, Mexico, 2004, 1-22(CD-ROM).

6. Amasaka, K., Applying New JIT -Toyota's global production strategy: Epoch- making innovation in the work environment, Robotics and Computer-Integrated Manufacturing, 23 (3), 2005, 285-293.

7. Amasaka, K., Science TQM, A New Quality Management Principle, International Symposium on Business and Industrial Statistics, Portugal, 2007, 1-14.

8. Amasaka, K., New Japan Production Method, An Advanced Production Management Principle - Key to Strategic Implementation of New JIT, The International Business \& Economics Research Journal, 2007, 6(7), 67-79

9. Amasaka, K. eds., New Japan Model - Science TQM: Theory and Practice of Strategic Quality Management, 2007, Maruzen, Tokyo. (in Japanese)

10. Amasaka, K. and S. Osaki, A Reliability of Oil Seal for Transaxle - A Science SQC Approach in Toyota, Case Studies in Reliability and Maintenance, John Wiley \& Sons, Inc, 2002, 571-581

11. Amasaka, K. and M. Yamaji, Advanced TDS, Total Development Design Management Model: Application to Automotive Intelligence CAE Methods utilizing New JIT, Refereed Proc. of The International Business \& Economics Research Conference, Cancun, Mexico, 2006, 1-15 (CD-ROM).

12. Burke, R., J. Graham, and F. Smith, Effects of reengineering on the employee satisfaction-customer satisfaction relationship, The TQM Magazine, 17(4), 2005, 358-363.

13. Evans, J. R. and W. M. Lindsay, The Management \& Control of Quality, 1995, South-Western, Cincinnati.

14. Goto, T., Forgotten the origin of management, 1999, Seisansei-syuppan, Tokyo (in Japanese).

15. Hoogervorst, J. A. P., P. L. Koopman and H. van der Flier, Total quality management: The need for an employeecentered coherent approach, The TQM Magazine, 17(1), 2005, 92-106.

16. Kakkar S., and A.S.Narag, Recommending a TQM model for Indian organizations, The TQM Magazine, 19(4), 2007, 328-353

17. Lagrosen, S., Quality management in global firms, The TQM Magazine, 16(6), 2004, 396-402.

18. Ljungström, M., A model for starting up and implementing continuous improvements and work development in practice, The TQM Magazine, 17(5), 2005, 385-405.

19. Ohno, T., Toyota Production System, 1977, Diamond-sha, Tokyo (in Japanese).

20. Prajogo D., Progress of quality management practices in Australian manufacturing firms, The TQM Magazine, 18(5), 2006, 501-513

21. Roos, D., et al., The Machine that change the World - The Story of Lean Production, 1990, Rawson/Harper Perennial, New York.

22. Taylor, D. and D. Brunt, Manufacturing Operations and Supply Chain Management - The Lean Approach-, 2001, Thomson Leaning, Florence.

23. Womack, J. P. and D. Jones, From Lean Production to the Lean Enterprise, Harvard Business Review, MarchApril, 1994, 93-103.

24. Yamaji, M., K. Suzuki, K. Shimizu, T. Ishizuka and K. Amasaka, Revolutions in QA \& TQM, Key to the Success of Globalized Quality Management- Implementation of New Japan Model Science TQM-, Proc. of the 23rd Annual Conference of Japanese Society for Production Management, Osaka, Japan, 2006, 85-88 (in Japanese).

25. Yamaji, M., H. Sakai, and K. Amasaka, Evolution of Technology and Skills in Production Workplaces utilizing Advanced TPS, Journal of Business \& Economics Research, 5(6), 2007, 61-68.

26. Yamaji, M. and K. Amasaka, New Japan Quality Management Model, Hyper-cycle model QA \& TQM Dual System" - Implementation of New JIT for Strategic Management Technology -," Proc. of the International Manufacturing Leaders Forum, Taipei, Taiwan, 2006, 1-6.(CD-ROM) 